\title{
Spatial association of fruit yield of Bertholletia excelsa Bonpl. trees in eastern Amazon
}

\author{
Anderson Pedro Bernardina Batista ${ }^{\mathrm{a}, \mathrm{b}, *}$, Henrique Ferraco Scolforo ${ }^{\mathrm{c}}$, José Márcio de Mello ${ }^{\mathrm{a}}$, \\ Marcelino Carneiro Guedes ${ }^{\mathrm{d}}$, Marcela Castro Nunes Santos Terra ${ }^{\mathrm{a}}$, João Domingos Scalon ${ }^{\mathrm{e}}$, \\ Lucas Rezende Gomide $^{\mathrm{a}}$, Paula Gomides Vitor Scolforo ${ }^{\mathrm{a}}$, Rachel L. Cook ${ }^{\mathrm{c}}$ \\ ${ }^{a}$ Department of Forest Science, Federal University of Lavras, LEMAF, Campus Universitário, Campus Box 3037, Lavras, Minas Gerais 37200-000, Brazil \\ ${ }^{\mathrm{b}}$ Instituto Federal do Amazonas, campus São Gabriel da Cachoeira, Amazonas 69750-000, Brazil \\ ${ }^{\mathrm{c}}$ Department of Forestry and Environmental Resources, North Carolina State University, 2800 Faucette Dr., Campus Box 8001, Raleigh, NC 27695, United States \\ d Empresa Brasileira de Pesquisa Agropecuária (Embrapa Amapá), Rodovia Juscelino Kubitscheck km05, Macapá, Amapá, Brazil \\ ${ }^{\mathrm{e}}$ Department of Statistic, Federal University of Lavras, Campus Universitário, Campus Box 3037, Lavras, Minas Gerais 37200-000, Brazil
}

\section{A R T I C L E I N F O}

\section{Keywords:}

Brazil nut

Bivariate Ripley's K-function

Modeling

\begin{abstract}
A B S T R A C T
Brazil nut (Bertholletia excelsa) is one of the most important non-timber forest product (NTFP) species in the world. Better management and conservation practices will only be possible with an in-depth knowledge of tree species ecology. This study aimed to assess the spatial association of fruit yield of Bertholletia excelsa (B. excelsa) trees in two forest types (old growth terra firme forest and Amazon-cerrado transitional forest) in the Brazilian Amazon. Fruit yield was measured in both forest types during 2010. At each forest type, fruit yield was divided into different yield classes (number of fruits) for subsequent spatial modeling. The bivariate Ripley's $K$-function was applied to quantify the spatial association of fruit yield of $B$. excelsa trees over different fruit yield classes. The results revealed that the forest type influences the spatial association of $B$. excelsa fruit yield. The old growth terra firme forest presented random spatial association for fruit yield, which implies that fruit yield of $B$. excelsa trees in this forest type is not limited by tree location and site resources. On the other hand, the Amazon-cerrado transitional forest presented significant negative spatial association for fruit yield across different yield classes, which means that under some conditions fruit yield of a given tree influences the fruit yield of the neighboring tree in this forest type. Site resources in the Amazon-cerrado transitional forest is limited and naturally favors inter- and intra-specific competition. Finally, the results imply the need for adoption of different management and conservation strategies for $B$. excelsa in different forest types in the Brazilian Amazon.
\end{abstract}

\section{Introduction}

In South America, one of the most important non-timber forest products (NTFP) is the Brazil nut, which is extracted from the Bertholletia excelsa (B. excelsa) tree in native Amazon forests (Wadt et al., 2005; Shepard and Ramirez, 2011). B. excelsa occurrence spans the entire Amazon region including countries such as Brazil, Venezuela, Colombia, Peru, Bolivia, Suriname, Guyana, and French Guiana (Wadt et al., 2005). Brazil, Peru and Bolivia are the leader producing and exporting countries in the world of this NTFP.

At present, the major challenge for the sustainable commercialization of this NTFP is the trade-off in maximizing the yearly level of $B$. excelsa fruit yield without compromising the tree's ecological sustainability (Kainer et al., 2007). A key point to accomplish this challenge is through the proper understanding of $B$. excelsa fruit yield in the Brazilian Amazon across different forest types. It is widely accepted that this understanding is a complex task, since the number of fruits varies depending upon on several factors (Kainer et al., 2007). Stand density and soil resources effect fruit yield of $B$. excelsa trees and can be indirectly inferred through the understanding and estimation of the $B$. excelsa tree location $\times$ fruit yield interaction.

Estimation of the $B$. excelsa tree location $\times$ fruit yield interaction remains uninvestigated (Guedes et al., 2014). Hence, investigation of this interaction is an important step for a better understanding of the tree species ecology, which naturally enables better species management. Hart and Marshall (2009) reported that studies evaluating tree

\footnotetext{
* Corresponding author at: Department of Forest Science, Federal University of Lavras, LEMAF, Campus Universitário, Campus Box 3037, Lavras, Minas Gerais 37200-000, Brazil.

E-mail address: anderson.batista@ifam.edu.br (A.P.B. Batista).
} 


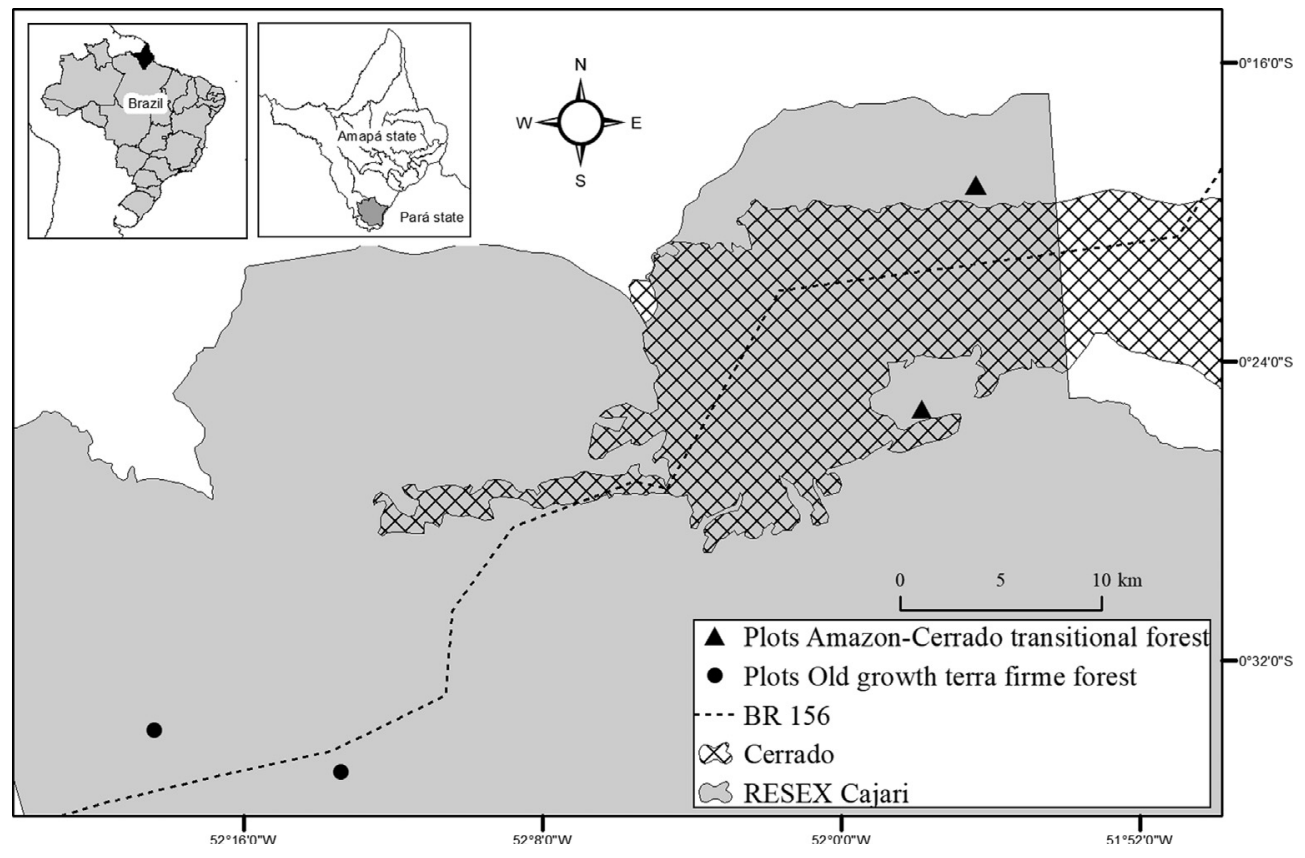

Fig. 1. Study area with plot location (P1, P2, P3, and P4).

location $\times$ tree attribute interaction helps supporting analysis focused on understanding habitat preference as well as the inter- and intraspecific tree competition for site resources.

Some studies have explored the spatial association of certain tree species (tree location $\times$ tree attribute interaction) in tropical forests (Condit et al., 2000; Wadt et al., 2005; Thomas et al., 2015; Fibich et al., 2016). Condit et al. (2000) evaluated the tree location $\times$ tree average density of conspecific tree interaction in Central America tropical forests. The authors verified similar behavior for all studied forests, in which the rare tree species are conventionally more aggregated than common species in the forests. Thomas et al. (2015) tested the hypothesis that $B$. excelsa trees spread in the Amazon was influenced by ancient humans. The authors found a statistically significant $B$. excelsa tree location $\times$ tree occurrence interaction and their results confirmed the ancient human influence on $B$. excelsa stand distribution in the Amazon. Fibich et al. (2016) studied tree location $\times$ tree species density and size interaction in primary and secondary lowland rain forests in New Guinea. The authors reported that higher tree species diversity in primary forests when compared to secondary forests are related to the reduction of species clustering.

The assessment of the spatial association of certain tree species (tree location $\times$ tree attribute interaction) is important in ecological theory (Condit et al., 2000). Understanding of the spatial dispersion of trees in tropical forests is desired, since it is assumed that spatial patterns can affect community processes (Stoll and Bergius, 2005). It is commonly hypothesized that statistically significant tree location $\times$ tree attribute interaction increases the importance of understanding the effect of competition for site resources (Pacala and Levin, 1977). This naturally helps supporting analyses for the definition of the most proper management for the tree species.

Despite the importance of $B$. excelsa in the Amazon, there is a dearth of studies focused on: (1) the investigation of spatial association of $B$. excelsa fruit yield, i.e., investigation of tree location $\times$ fruit yield interaction; (2) the investigation of this spatial association at different scales and different forest types. Hence, this study aimed to: (1) quantify the spatial association of fruit yield of $B$. excelsa trees in different forest types (old growth terra firme forest and Amazon-cerrado transitional forest) in the Brazilian Amazon; and (2) reveal whether a $B$. excelsa tree can limit the fruit yield of other trees.

We hypothesized that revealing the spatial association of fruit yield in different forest types is desirable to enable sustainable fruit yield collection over the years, since it helps protect the tree species as well as allows for the perpetuity of the economic activity of traditional extractivism communities.

\section{Material and methods}

\subsection{Characterization of the study area}

The study area is located in the Extractive Reserve Rio Cajari (Resex Cajari). Resex Cajari is a conservation unit of 501,771 ha, located at the southernmost part of the Amapá state (Brasil, 1990). Resex Cajari is part of the Brazilian System of Nature Conservation Units and is classified as an area under use of traditional extractivism communities. The subsistence of these communities is based on extractive activities, agriculture, and small animal husbandry. Hence, the main goals of the Resex Cajari are to protect the livelihood and culture of the extractivism communities as well as to ensure the sustainable use of natural resources (Brasil, 2000).

The Resex Cajari climate, according to Köppen classification, is at the transition point between tropical savanna climate (Aw) and tropical monsoon climate (Am) (Alvares et al., 2013). The region presents mean annual temperature of $25^{\circ} \mathrm{C}$, with a minimum of $18^{\circ} \mathrm{C}$ and maximum of $31.5^{\circ} \mathrm{C}$. The annual rainfall is of approximately $2300 \mathrm{~mm}$, with a long rainy season from December to June. According to the Brazilian soil classification system, the old growth terra firme forest of Resex Cajari mostly presents Oxisols, while the Amazon-cerrado transitional forest mostly presents Ultisols (Santos et al., 2015). Resex Cajari is at approximately $150 \mathrm{~m}$ above the sea level.

\subsection{Database}

The study area is located in high-density regions of $B$. excelsa trees. The sampled forests are considered active for seed collection (Paiva et al., 2011). Two forest type sites composed the study area: old growth terra firme forest (IBGE, 2012) and Amazon-cerrado transitional forest (Neves et al., 2016). It is worth mentioning that the extractivism communities apply similar fruit yield collection for both forest types, i.e., every year nuts are collected in these regions, although no management regime is applied to ensure future fruit yield. 
Table 1

Number of $B$. excelsa trees per hectare (B. excelsa), coefficient of variation of fruit yield of $B$. excelsa trees (CV, \%), number of different tree species per hectare (S), basal area (B) and stand density of the surrounding vegetation per hectare $(\mathrm{N})$ in the different plots at each forest type.

\begin{tabular}{lllllll}
\hline Plot & Forest type & B. excelsa & CV (\%) & $\begin{array}{l}\mathrm{S} \text { (species/ } \\
\text { ha) }\end{array}$ & $\begin{array}{l}\mathrm{B}\left(\mathrm{m}^{2} /\right. \\
\text { ha) }\end{array}$ & $\begin{array}{l}\mathrm{N} \text { (trees/ } \\
\text { ha) }\end{array}$ \\
\hline P1 & Old growth terra & 7 & 127 & 19 & 31.0 & 946 \\
P2 & firme forest & 4 & 106 & 26 & 36.6 & 1625 \\
P3 & Amazon-cerrado & 13 & 106 & 21 & 37.8 & 1882 \\
P4 & transitional forest & 10 & 111 & 22 & 35.6 & 1410 \\
\hline
\end{tabular}

Four $300 \times 300 \mathrm{~m}$ permanent plots ( 9 ha each permanent plot) (Paiva et al., 2011; Neves et al., 2016) were installed in 2010, where two plots (P1 and P2) are located in the old growth terra firme forest, while the other two plots (P3 and P4) are located in the Amazon-cerrado transitional forest (Fig. 1).

Only two plots were installed in each forest type due to budgetary constraints (Guedes et al., 2017). These plots, however, were installed in a framework to better cover the spatial variability presented by each forest type. The plots were installed in stands that display great difference between each other, which helps quantifying fruit yield collection in stands with low and high productivity in each forest type (Table 1).

At each plot, B. excelsa trees with diameter at $1.30 \mathrm{~m}$ above ground (diameter at breast height, DBH in $\mathrm{cm}$ ) greater than or equal to $10 \mathrm{~cm}$ were measured and georeferenced with a Global Positioning System (GPS) (Garmin 62sc). Only B. excelsa trees that yielded fruits were used in this study, therefore smaller trees (DBH typically $\leq 35 \mathrm{~cm}$ ) were discarded in this study.

Surrounding vegetation (trees with DBH greater than or equal to $3 \mathrm{~cm}$ ) around the $B$. excelsa trees was also measured to provide an idea of the forest diversity and stand density. A total of 40 subplots, with size of $10 \times 25 \mathrm{~m}$, systematically distributed within each permanent plot were installed. Consequently, it was possible to have a measure of stand density and diversity in each permanent plot at each forest type.

Fruit yield (at each tree) was measured through counting the fruits fallen under each tree crown. At this step, fruit collection followed a real extractivism activity. This implies that the field team followed the nut harvesters. Hence, fruits were collected at the same period and by using the same tools and traditional practices of extractivism people. Fruit yield was defined as the total number of fruits per tree (at the time of fruit collection - February to April 2010). It is worth mentioning that although fruit yield collection through several years is desired, budgetary constraints in this research project allowed for fruit yield collection only in 2010. It is also important to mention that the extractivism communities reported a minimum fruit yield yearly variation, which naturally helps increase the confidence in the findings highlighted in this study.

Fruit yield for each tree was defined as the number of fruits identified per tree. Fruits fallen under overlapping crowns of $B$. excelsa trees, however, were excluded from the database. Finally, fruit yield was divided into different yield classes (number of fruits) for subsequent spatial analysis (Table 2).

\subsection{Spatial modeling}

The bivariate $K$-function proposed by Lotwick and Silverman (1982) [as an extension of the univariate $K$-function (Ripley, 1976)] was used to quantify the spatial association of fruit yield of $B$. excelsa trees in each studied forest type. Hence, the spatial modeling was used for the assessment of tree location $\times$ fruit yield interaction in the Amazoncerrado transitional forest as well as for old growth terra firme forest.

The bivariate $K$-function combines two distributions and was previously used to verify the spatial co-association of two different tree
Table 2

Yield classes with the range of fruits per class and the respective number of $B$. excelsa trees in each yield class in the different forest types of the Brazilian Amazon.

\begin{tabular}{llllll}
\hline $\begin{array}{l}\text { Fruit } \\
\text { yield } \\
\text { class }\end{array}$ & $\begin{array}{l}\text { Range of } \\
\text { fruits per } \\
\text { class }\end{array}$ & $\begin{array}{l}\text { Number of } \\
\text { trees in P1 }\end{array}$ & $\begin{array}{l}\text { Number of } \\
\text { trees in P2 }\end{array}$ & $\begin{array}{l}\text { Number of } \\
\text { trees in P3 }\end{array}$ & $\begin{array}{l}\text { Number of } \\
\text { trees in P4 }\end{array}$ \\
\hline 1 & $<25$ & 62 & 34 & 119 & 87 \\
2 & $25-50$ & 55 & 30 & 53 & 56 \\
3 & $50-100$ & 44 & 25 & 30 & 42 \\
4 & $100-200$ & 36 & 20 & 11 & 17 \\
5 & $150-200$ & 23 & 13 & 3 & 13 \\
6 & $200-250$ & 13 & 9 & 1 & 6 \\
7 & $250-300$ & 6 & 9 & - & 4 \\
8 & $300-350$ & 3 & 7 & - & 1 \\
9 & $>350$ & 3 & 5 & - & - \\
\hline
\end{tabular}

$\mathrm{P} 1, \mathrm{P} 2, \mathrm{P} 3$ and $\mathrm{P} 4=$ plots $1,2,3$ and 4 , respectively.

species (Flugge et al., 2014) as well as the spatial association of trees in neotropical forests (Ledo, 2015). The bivariate function $\widehat{K}_{12}$ (h) refers to the estimator of the bivariate $K$-function for variable 1 (tree 1 ) in relation to variable 2 (neighboring tree 1 ). For instance, $\widehat{K}_{12}(\mathrm{~h}$ ) values were generated for the combination of each tree in a given yield class with all its neighboring trees not presented in that given yield class (and above that given yield class). Distances between trees and their neighboring trees are different and justify the $\widehat{K}_{12}(\mathrm{~h})$ values for different distances.

$\widehat{K}_{12}(h)=\frac{|A|}{n_{1}^{2} n_{2}^{2}} \sum_{i=1}^{n 1} \sum_{i=1}^{n 2} \frac{I_{h}\left(u_{i j}\right)}{w_{i j}}$

where $\widehat{K}_{12}(h)$ is the estimator of the bivariate $K$-function; $h$ is the radius of the circle centered on each event; $I_{h}\left(u_{i j}\right)$ is a weight function, equal to 1 (when the distance is shorter than that of $h$ ) and 0 (when the distance is longer than that of $h$ ); $n_{1}$ and $n_{2}$ are the numbers of events of the first and second processes with area $|A|$; and $w_{i j}$ is a correction factor that represents the proportion of the circumference around an event $i$, over the event $j$, which is inside $|A|$, considering the following relation of the variables: $w_{i j}=\left(n_{1} w_{i j}+n_{2} w_{i j}\right) /\left(n_{1}+n_{2}\right)$. To simplify the result interpretation as well as to easily stabilize the variance of the $K$ estimator, we decided to use a linear estimator centered around zero in the function, namely function $L$, following the equation below (Diggle, 2003):

$\widehat{L}(h)=\sqrt{\frac{\widehat{K}_{12}(h)}{\pi}}-h$

where, all variables are previously defined.

The strategy of clustering fruit yield in classes (as presented in Table 2) is justified, since this clustering excluded possible spatial modeling problems due to lack of data. Thus, clustering fruit yield in classes enabled for the assessment of the effect of high productive $B$. excelsa trees on low productive $B$. excelsa trees in two different forest types (Amazon-cerrado transitional forest and old-growth terra firme forest).

\subsubsection{Hypothesis testing}

The null hypothesis of the bivariate $K$-function assumed a random spatial association (RSA) of fruiting, which means that tree location $\times$ fruit yield interaction is not statistically significant and therefore fruit yield in a given forest type is not limited by site resources or by neighboring trees. In order to evaluate the null hypothesis of RSA, confidence envelopes were created following Diggle (2003). Hence, Monte Carlo's simulations were used to generate ninety-nine simulations, in which the maximum and minimum $\widehat{K}_{12}$ values for each distance $h$ were recorded.

Subsequently, the confidence envelopes were generated, where graphical analyses enabled the visual assessment of the validity of the 
null hypothesis. The significance level was given by $\alpha=2 /(s+1)$, where $s$ is the number of simulations. The minimum and maximum $\widehat{K}_{12}$ values generated from the simulations defined the limits of the confidence envelope. Hence, these limits and the $\widehat{K}_{12}$ values generated from Eq. (1) were plotted as function of $h$. The null hypothesis (RSA) is rejected when the $\widehat{K}_{12}$ values are outside of the limits of the confidence envelope, which implies that there is a co-association of tree location and fruit yield.

If the $\widehat{K}_{12}$ values are above the maximum limit at a given $h$, we assume that there is a positive spatial association of fruit yield through different yield classes. If the $\widehat{K}_{12}$ values are below the minimum limit at a given $h$, we assume that there is a negative spatial association of fruit yield through different yield classes. A negative spatial association implies that the forest type does not favor fruit yield among $B$. excelsa trees, while the positive spatial association states the opposite.

The spatstat package (Baddeley and Turner, 2005) through the use of the R software (R Core Team, 2017) was used for all analyses.

\section{Results}

\subsection{Descriptive statistics}

The study area is known for its high density of $B$. excelsa trees in the two forest types (Fig. 2).

Plots 3 and 4 (P3 and P4) in the Amazon-cerrado transitional forest displayed higher numbers of $B$. excelsa trees when compared to Plots 1 and 2 (P1 and P2) in the old growth terra firme forest. It is worth mentioning that while $\mathrm{P} 1$ and $\mathrm{P} 2$ present less $B$. excelsa trees than $\mathrm{P} 3$ and P4, the opposite behavior is verified for fruit yield, since fruit yield is higher in the old growth terra firme forest when compared to the Amazon-cerrado transitional forest (Fig. 3).

It is worth mentioning that the poorer soils in the Amazon-cerrado transitional forest indirectly implies higher competition for site resources, which consequently tends to decrease fruit yield. Finally, even P2 (in the old growth terra firme forest) presenting higher stand density than P4 (in the Amazon-cerrado transitional forest), better soils found in the $B$. excelsa stands in the old growth terra firme forest mitigate the stand density effect on fruit yield of $B$. excelsa trees in this forest type.

\subsection{Fruit yield $\times$ tree location interaction - spatial association of fruit yield} of B. excelsa trees in the Brazilian Amazon

In the old growth terra firme forest (P1 and P2), the random spatial association (RSA) hypothesis was accepted for different $h$ 's. The $\widehat{K}_{12}$ values generated from Eq. (1) (continuous line) always remained within the confidence envelope (Fig. 4). This result implies that B. excelsa trees with high and low fruit yield in this forest type did not show any spatial association. This means that fruit yield of $B$. excelsa trees in the old growth terra firme forest is not affected by tree location and the interand intra-specific competition for site resources are neither mutually increasing fruit yield nor decreasing fruit yield of $B$. excelsa trees. This result highlights that site resources are not limiting fruit yield in this forest type.

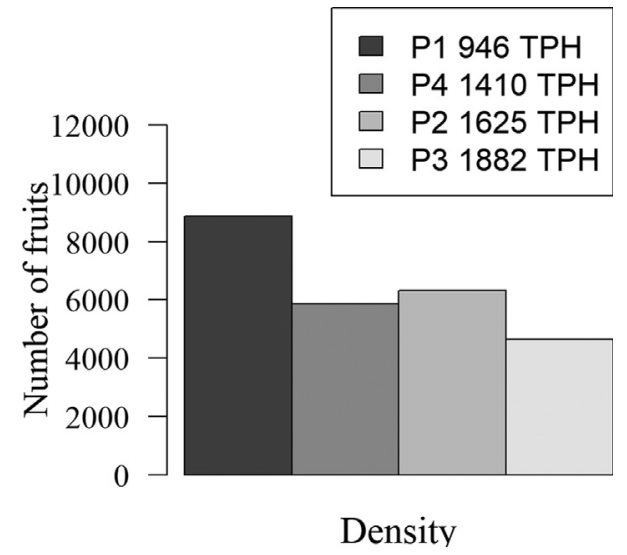

Fig. 3. Total number of collected fruits vs the stand density of the surrounding vegetation in each plot at each forest type.

On the other hand, the RSA hypothesis was rejected for some $h$ 's in the Amazon-cerrado transitional forest type, in which negative spatial association were conventionally verified (Fig. 5). In contrast to the results reported for the old growth terra firme forest, the results in the Amazon-cerrado transitional forest revealed that tree location and the inter- and intra-specific competition for site resources decrease fruit yield of $B$. excelsa trees. This result highlights that site resources are limiting fruit yield in this forest type.

For P3, RSA hypothesis was rejected in the fruit yield class 1 for h's greater than $30 \mathrm{~m}$, and negative spatial association was verified for this fruit yield class. Thus, trees with fruit yield class $>25$ (all trees not presented in yield class 1) limit fruit yield of trees that produced $<25$ fruits (tree in yield class 1 ) at $h$ greater than $30 \mathrm{~m}$, which implies that competition tends to favor larger trees (Fig. 5a).

Similar behavior was observed for the yield class 2 in P3 (Fig. 5b). The difference was that RSA was only rejected for $h$ between 30 and $60 \mathrm{~m}$. Fruit yield class 3 presented similar results to those of yield class 2 for P3 (Fig. 5c). The RSA hypothesis was rejected for yield class 4 for $h$ between 20 and $70 \mathrm{~m}$, and again the confidence envelope revealed negative spatial association (Fig. 5d). Similar behavior of P3 was observed for P4. Negative spatial association was verified by the confidence envelopes (Fig. 5f, g, h, j, k).

\section{Discussion}

The spatial analysis revealed a random spatial association for the trees of the old growth terra firme forest (P1 and P2). The tree location $\times$ fruit yield interaction is not statistically significant, which means that soil resources are not limiting fruit yield in this forest type. Hence, we can hypothesize that the combination of $B$. excelsa tree size, surrounding vegetation density and soil condition presented in this forest type does not limit B. excelsa fruit yield (Saboya and Borghetti, 2012). On the other hand, negative spatial association was verified in the Amazon-cerrado transitional forest (P3 and P4). This implies that
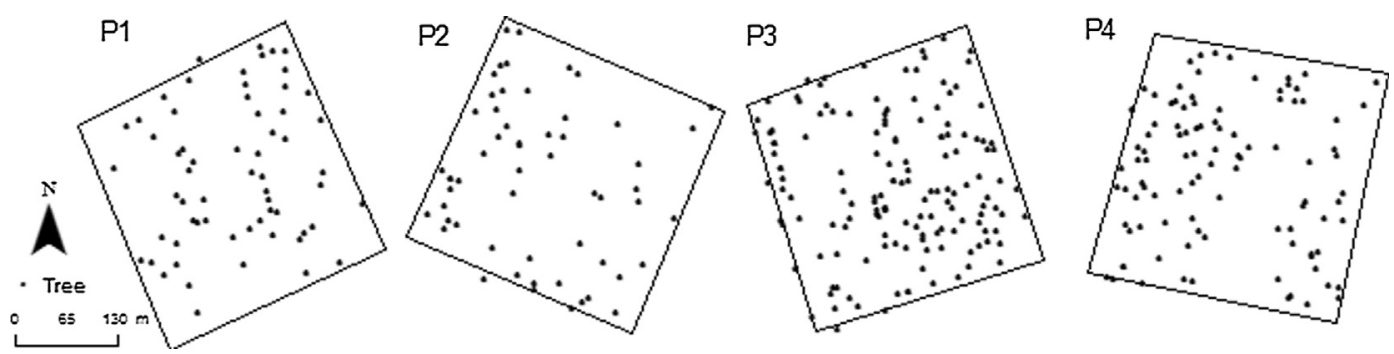

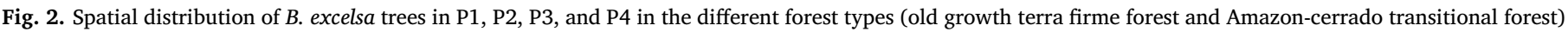
in the Brazilian Amazon. 


\section{Old growth terra firme forest}

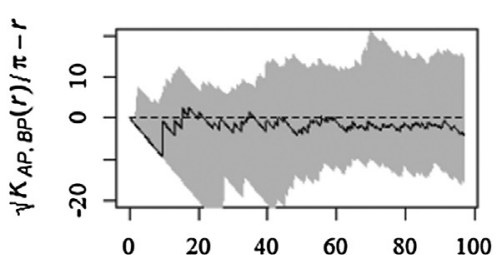

a)
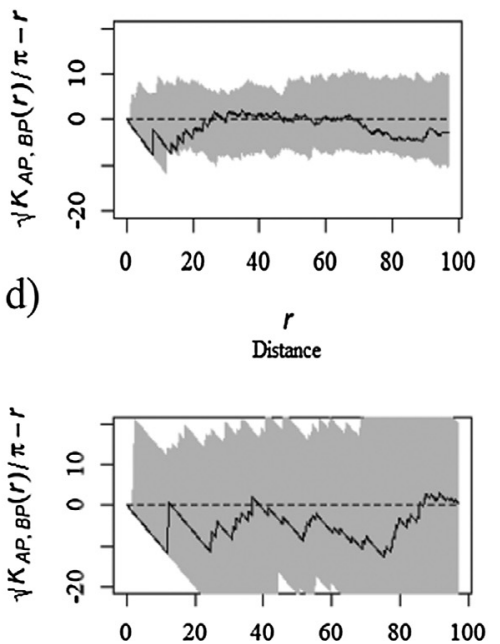

g)

$r$

Distance

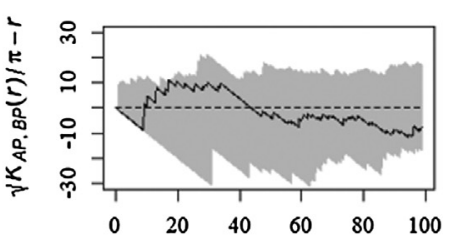

j)

Distance

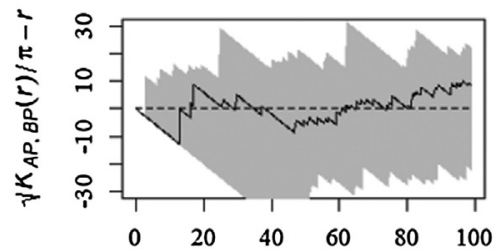

m)

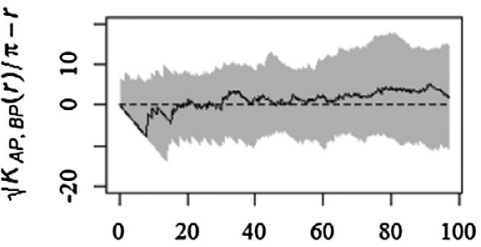

b)
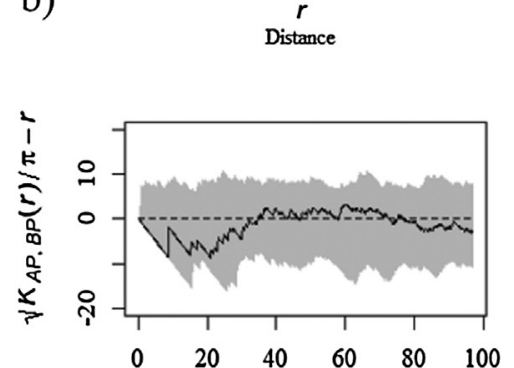

e)
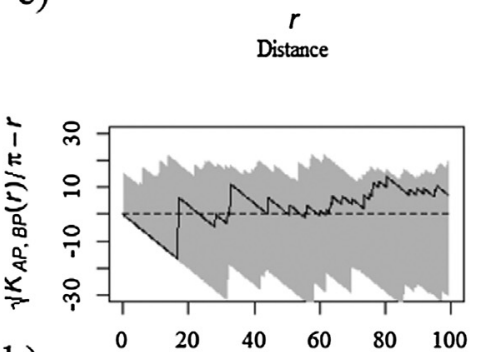

h)
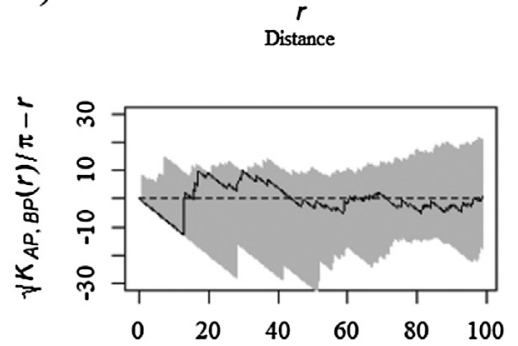

k)

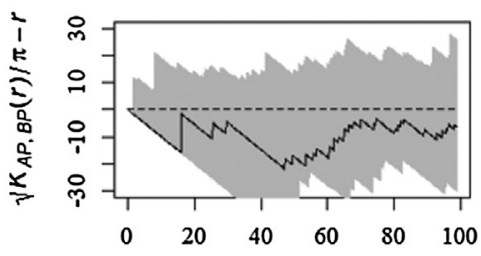

n)

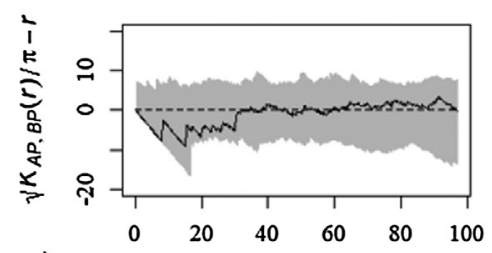

c)
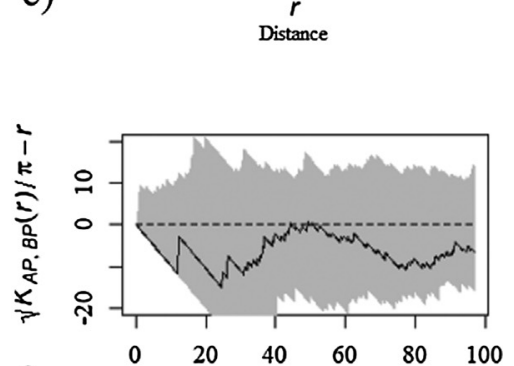

f)

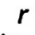

Distance

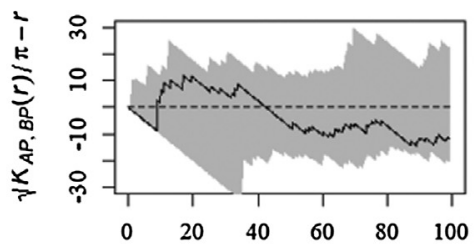

i)

$r$

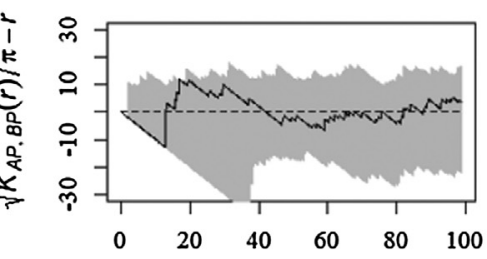

1)

Distance

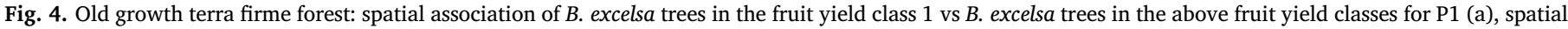

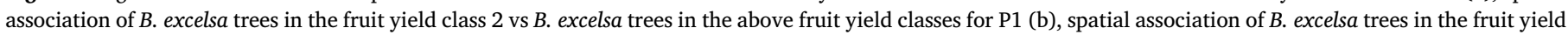

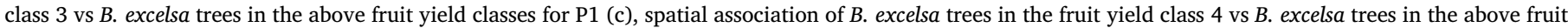

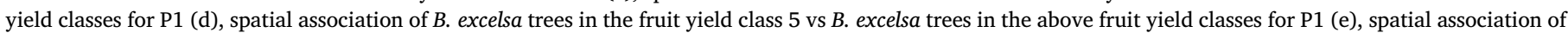

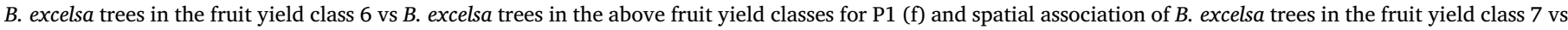

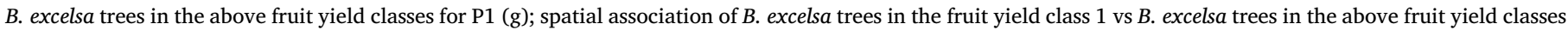

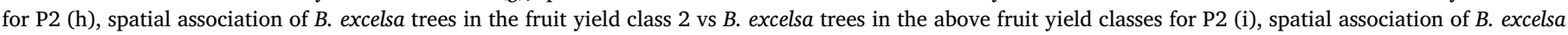

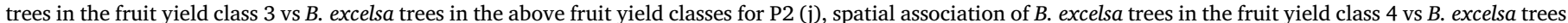

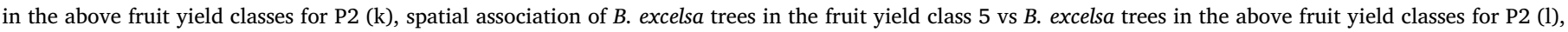

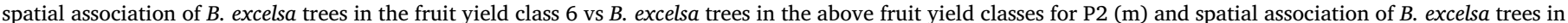

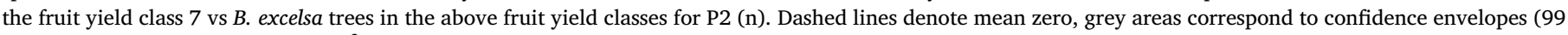
simulations) and solid line denotes $\widehat{K}_{12}$ values generated from Eq. (1). 


\section{Amazon-Cerrado transitional forest}

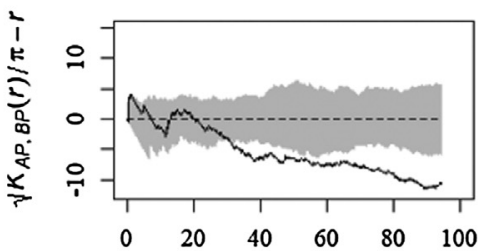

a)
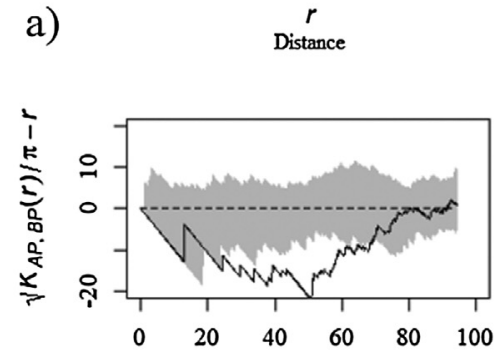

d)
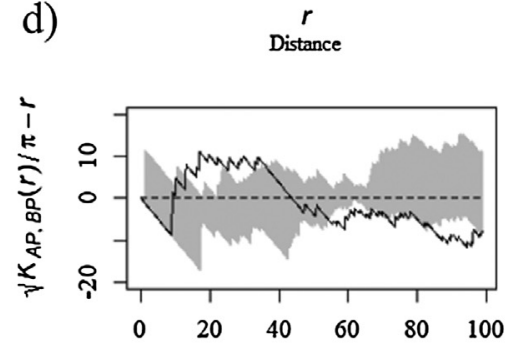

g)
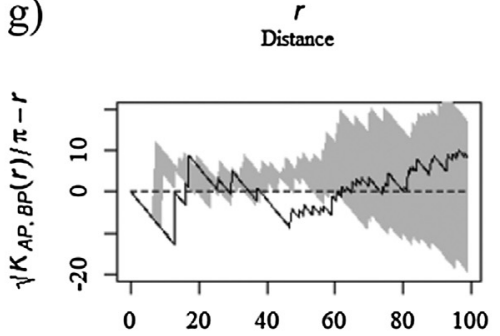

j)

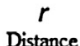

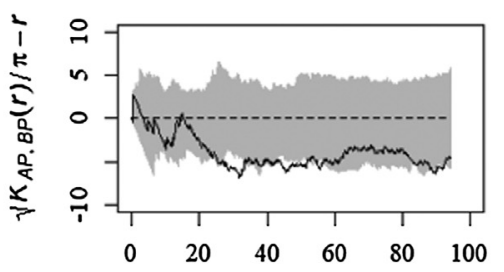

b)
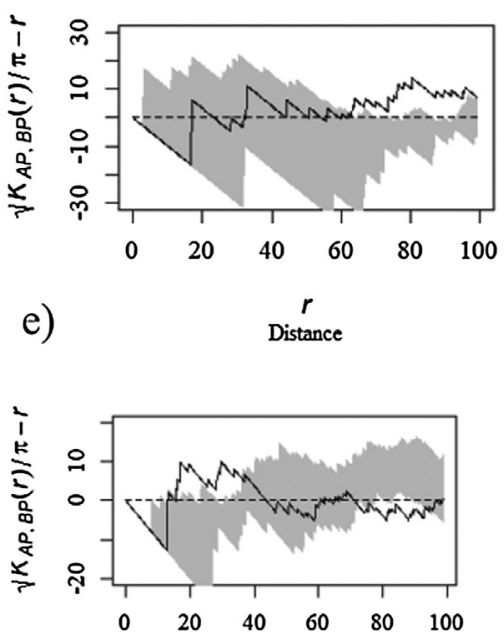

h)

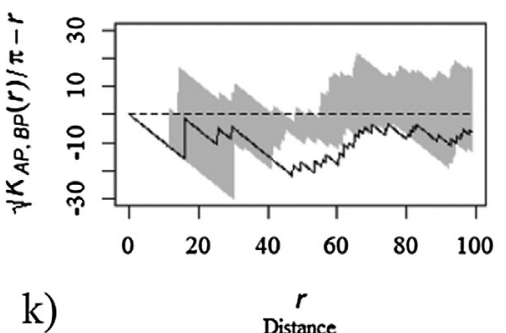

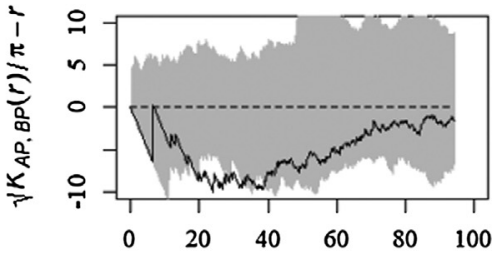

c)
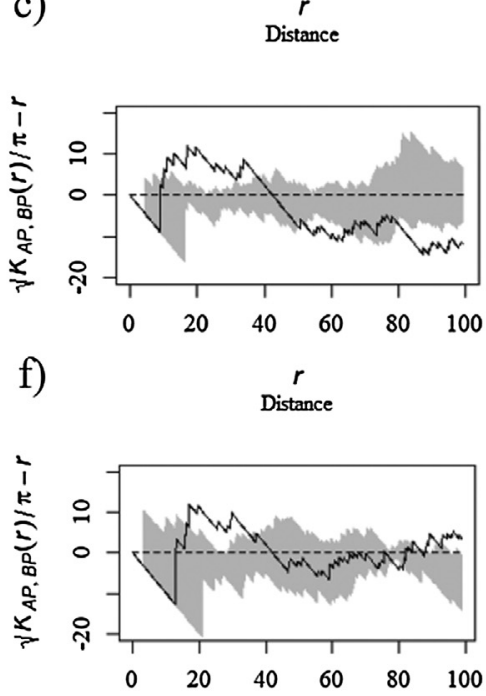

i)

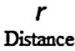

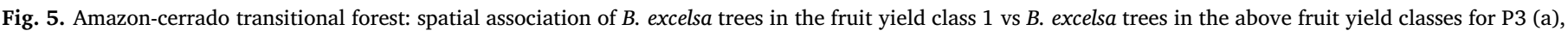

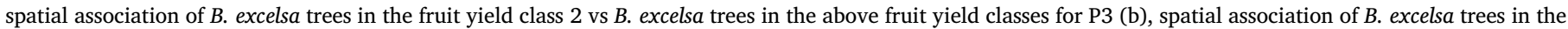

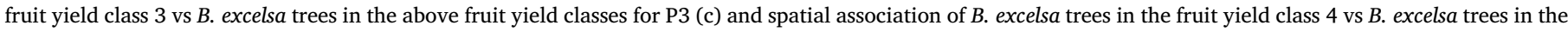

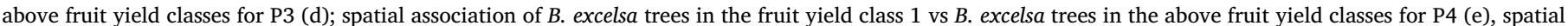

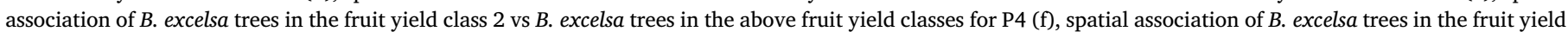

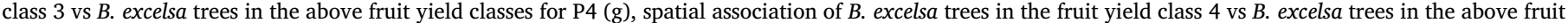

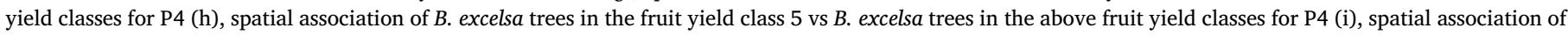

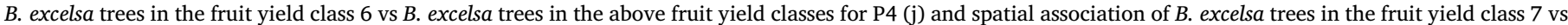

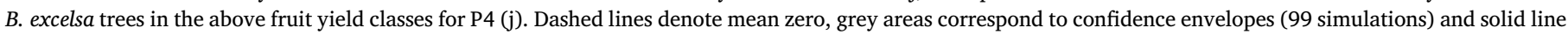
denotes $\widehat{K}_{12}$ values generated from Eq. (1).

under some conditions fruit yield of a given tree influences the fruit yield of the neighboring tree in this forest type. This result might be related to the fact that site resource in this forest type is limited, which naturally favors inter- and intra-specific competition. Larger trees have the advantage when competing for site resources, therefore, the smaller trees tend to have lower nutrient and water availability for fruiting (Hart and Marshall, 2009).

Although only two plots were used for the evaluation of fruit yield at each forest type, these plots successfully represented the range in fruit yield variation observed in each forest type. While Kainer et al. (2007) reported that fruit yield varies up to $90 \%$ in the Eastern Amazon, we used plots with fruit yield variation in each forest type that was higher than $100 \%$, i.e., we were able to verify a higher variation in fruit yield of $B$. excelsa trees in both the Amazon-cerrado transitional forest and old-growth terra firme forest.

While the random spatial association among $B$. excelsa trees in the old growth terra firme implies that fruit yield does not depend of tree location and size, the different behavior verified for the Amazon-cerrado transitional forest highlights the need for different management strategy to enable sustainable fruit yield collection across the years. Getzin et al. (2008) reported that negative spatial association may reflect different behavior of the tree species with respect to intra- and interspecific-tree competition, which consequently results in different strategies of the tree species to survive over time as well as to fruit yield every year. Hence, it is worth mentioning that low intensity thinning every year in the surrounding vegetation might be suggested as one way to avoid high competition for site resources. This fact is a major challenge for the extractivism activity, since the activity aims to increase 
fruit yield without compromising the tree species ecological sustainability.

Finally, it is worth mentioning that the difference in site resource availability found in these two different forest types are related to past human disturbance as well. Humans have contributed to B. excelsa tree distribution in the Amazon, influencing its abundance in some Amazon regions, namely nowadays as "castanhais". The human historical influence might have been unintended, but it certainly influenced Brazil nut fruit yield. The occurrence of $B$. excelsa trees in the Amazonian old growth terra firme forests is concentrated in regions highly influenced by humans, denominated "Amazonian Dark Earth soils" and geoglyphs (Scoles and Gribel, 2011; Thomas et al., 2015). These are areas of high soil fertility (Moline and Coutinho, 2015). This fact positively affects fruit yield in the old growth terra firme forest. Thus, this forest may be less susceptible to fruit yield-limiting factors. Therefore, trees of higher fruit yield classes may occur at any point of the area, which is the opposite observed in the Amazon-Cerrado transitional forest.

A major drawback in this study is related to the lack of temporal analysis of fruit yield in the two different forest types. Although the extractivism communities reported a minimum fruit yield yearly variation, fruit yield data collection across several years is critical for the assessment of the tree species dynamics. Another important task is with regards to how unusual yearly climate variation impact fruit yield in each forest type, especially in the Amazon-cerrado transitional forest. Thus, we suggest future research to increase the number of measurements of fruit yield through successive years in these forest types as well as to increase the sample size in each forest type.

\section{Conclusions}

The bivariate $K$-function spatial analysis identified different spatial association of $B$. excelsa fruit yield in the studied forest types. The forest type appears to spatially influence $B$. excelsa fruit yield.

The present study emphasizes that fruit yield among $B$. excels $a$ trees presents no spatial association in the old growth terra firme forest. Conversely, the Amazon-cerrado transitional forest presented a negative spatial association of trees in the different fruit yield classes. These results reveal the need for the adoption of different management and conservation strategies for the tree species with respect to the forest type.

\section{Appendix A. Supplementary material}

Supplementary data to this article can be found online at https:// doi.org/10.1016/j.foreco.2019.03.043.

\section{References}

Alvares, C.A., Stape, J.L., Sentelhas, P.C., Gonçalves, J.L.M., Sparovek, G., 2013. Köppen climate classification map for Brazil. Meteorol. Z. 22, 711-728.

Baddeley, A., Turner, R., 2005. Spatstat: an R package for analyzing spatial point patterns. J. Stat. Softw. 12 (6), 1-42.

Brasil, 1990. Decreto $N^{\circ} 99.145$ de 12 de março de 1990, Criação da Reserva Extrativista do Rio Cajarí.

Brasil, 2000. Lei 9985/00 que Institui o Sistema Nacional de Unidade de Conservação da Natureza.

Condit, R., Ashton, P.S., Baker, P., Bunyavejchewin, S., Gunatilleke, S., Gunatilleke, N. Hubbell, S.P., Foster, R.B., Itoh, A., LaFrankie, J.V., Lee, H.S., Losos, E., Manokaran, N., Sukuwar, R., Yamakura, T., 2000. Spatial patterns in the distribution of tropical tree species. Science 288, 1414-1418. https://doi.org/10.1126/science.288.5470. 1414.

Diggle, P.J., 2003. Statistical Analysis of Spatial Point Patterns, 2nd ed. Oxford University Press.

Fibich, P., Lepš, J., Novotný, V., Kilmes, P., Tesitel, J., Molem, K., Damas, K., Weiblen, G.D., 2016. Spatial patterns of tree species distribution in New Guinea primary and secondary lowland rain forest. J. Veg. Sci. 27 (2), 328-339. https://doi.org/10.1111/ jvs.12363.

Flugge, A.J., Olhede, S.C., Murrell, D.J., 2014. A method to detect subcommunities from multivariate spatial associations. Met. Ecol. Evolut. 5, 1214-1224. https://doi.org/ 10.1111/2041-210X.12295.

Getzin, S., Wiegand, T., Wiegand, K., He, F., 2008. Heterogeneity influences spatial patterns and demographics in forest stands. J. Ecol. 96, 807-820. https://doi.org/10. 1111/j.1365-2745.2008.01377.x.

Guedes, M.C., Neves, E.S., Rodrigues, E.G., Paiva, P., Costa, J.B.P., Freitas, M.F., Lemos, L.M., 2014. 'Castanha na roça': expansão da produção e renovação dos castanhais em áreas de agricultura itinerante no Amapá, Brasil. Bol. Mus. Para Emílio Goeldi. Cienc. Nat. 9, 381-398.

Guedes, M.C., Tonini, H., Wadt, L.H.O., Silva, K.E., 2017. Instalação e medição de parcelas permanentes para estudos com produtos florestais não madeireiros. In: Wadt, L. H.O.; Santos, L.M.H.; Bentes, M.P.M.; Oliveira, V.B.V. (Ed.). Produtos florestais não madeireiros: guia metodológico da Rede Kamukaia. Brasília, DF: Embrapa, 2017, pp. 13-32.

Hart, S.P., Marshall, D.J., 2009. Spatial arrangement affects population dynamics and competition independent of community composition. Ecology 90 (6), 1485-1491. https://doi.org/10.1890/08-1813.1.

IBGE, 2012. Instituto Brasileiro de Geografia e Estatística. Manual técnico da vegetação brasileira: 1-271. IBGE (Manuais Técnicos em Geociências, 1), Rio de Janeiro.

Ledo, A., 2015. Nature and age of neighbours matter: interspecific associations among tree species exist and vary across life stages in tropical forests. PLoS One 10 (11), e0141387. https://doi.org/10.1371/journal.pone.0141387.

Kainer, K.A., Wadt, L.H.O., Staudhammer, C.L., 2007. Explaining variation in Brazil nut fruit production. For. Ecol. Manage. 250, 244-255. https://doi.org/10.1016/j.foreco. 2007.05.024.

Lotwick, H.W., Silverman, B.W., 1982. 1982 Methods for analysing spatial processes of several types of points. J. Royal Stat. Soc. 44, 406-413.

Moline, E.F.V., Coutinho, E.L.M., 2015. Atributos químicos de solos da Amazônia Ocidental após sucessão da mata nativa em áreas de cultivo. Ver. Cienc. Agrar. 58, 14-20. https://doi.org/10.4322/rca.1683.

Neves, E.S., Wadt, L.H.O., Guedes, M.C., 2016. Estrutura populacional e potencial para o manejo de Bertholletia excelsa (Bonpl.) em castanhais nativos do Acre e. Amapá. Sci. For. 44 (109), 19-31.

Pacala, S.W., Levin, S.A., 1997. Biologically generated spatial pattern and the coexistence of competing species. In: Tilman, D., Kareiva, P. (Eds.), Spatial Ecology. Princeton University Press, Princeton, NJ, US.

Paiva, P.M., Guedes, M.C., Funi, C., 2011. Brazil nut conservation through shifting cultivation. For. Ecol. Manage. 261 (3), 508-514.

R Core Team, 2017. R: A Language and Environment for Statistical Computing. R Foundation for Statistical Computing, Vienna. < http://www.R-project. org $>$ (accessed 20 January 2019).

Ripley, B.D., 1976. The second-order analysis of stationary point processes. J. Appl. Probab. 13, 255-266. https://doi.org/10.2307/3212829.

Saboya, P., Borghetti, F., 2012. Germination, initial growth, and biomass allocation in three native Cerrado species. Braz. J. Bot. 35, 129-135. https://doi.org/10.1590/ S0100-84042012000200002.

Santos, R.D., Curi, N., Shimizu, S.H., 2015. Guia Prático para Classificação de Solos Brasileiros, 1. ed. Produção independente - Publicado pelos Autores, Lavras, pp. 82p.

Scoles, R., Gribel, R., 2011. Population structure of Brazil nut (Bertholletia excelsa, Lecythidaceae) stands in two areas with diferente occupation histories in the Brazilian Amazon. Hum. Ecol. 39 (4), 455-464.

Shepard, G.H., Ramirez, H., 2011. "Made in Brazil": human dispersal of the Brazil Nut (Bertholletia excelsa, Lecythidaceae) in Ancient Amazonia. Econ. Bot. 65 (1), 44-65. https://doi.org/10.1007/s12231-011-9151-6.

Stoll, P., Bergius, E., 2005. Pattern and process: competition causes regular spacing of individuals within plant populations. J. Ecol. 93, 395-403.

Thomas, E., Caicedo, C.A., Mcmiche, C.H., Corvera, R., Loo, J., 2015. Uncovering spatial patters in the natural and human history of Brazil nut (Bertholletia excelsa) across the Amazon Basin. J. Biogeogr. 42 (1367-1382), 2015. https://doi.org/10.1111/jbi. 12540.

Wadt, L.H.O., Kainer, K.A., Gomes-Silva, D.A.P., 2005. Population structure and nut yield of a Bertholletia excelsa stand in Southwesterns Amazonian. For. Ecol. Manage. 211 (3), 371-384. https://doi.org/10.1016/j.foreco.2005.02.061. 